\title{
NEW SOLUTION OF THE TECHNOLOGICAL Process of Pressure Casting Die
}

\author{
WOLNY, R.; Zloto, T. \& Rygallo, A.
}

Abstract: In this paper new solution of the technological process of movable and immovable pressure casting die insert of pump executed in one of motor industrial plant was presented.

Machining processes of casting die elements were described in detail. Individual operations and the process of machining parameters selection were characterized. Machine applications were generated for the virtual $3 D$ model of movable and immovable die inserts in Mastercam application operating in Windows environment. An attempt at modification of technological process for selected HSM-applied milling operations (high-speed machining) in Mastercam was made.

As the result of modifications it turned out that machining time of rough milling operation has been significantly reduced, which means achieving considerable savings.

Key words: pressure casting die, technological process, machine tool, HSM, optimization
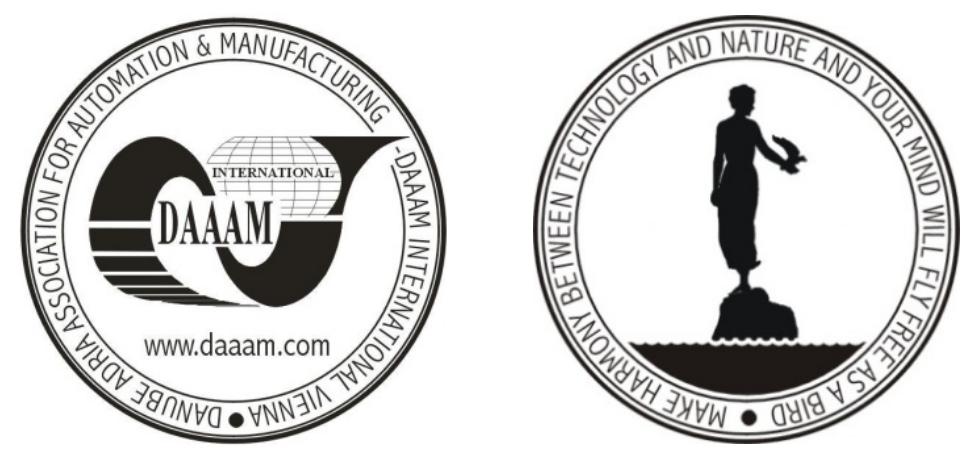

Authors' data: Dr. Wolny, R[yszard]; Prof. Zloto, T[adeusz]; Dr. Rygallo, A[ndrzej], Technical University of Czestochowa, Dabrowskiego 69, 42-200 Czestochowa, Poland, rwolny@itm.pcz.pl, zlotot@o2.pl, andryg@pro.onet.pl

This Publication has to be referred as: Wolny, R[yszard]; Zloto, T[adeusz] \& Rygallo, A[ndrzej] (2009). New Solution of the Technological Process of Pressure Casting Die, Chapter 83 in DAAAM International Scientific Book 2009, pp. 865-872, B. Katalinic (Ed.), Published by DAAAM International, ISBN 978-3-901509-69-8, ISSN 1726-9687, Vienna, Austria

DOI: 10.2507/daaam.scibook.2009.83 